Success at work requires successful leaders? The elements of successful leadership according to leaders and employees of a Finnish mid-size enterprise

\author{
Uusiautti, Satu $₫$ \\ Faculty of Education, University of Lapland, Finland (satu_uusiautti@hotmail.com)
}

Received: 30 March 2015

Available Online: 8 June 2015

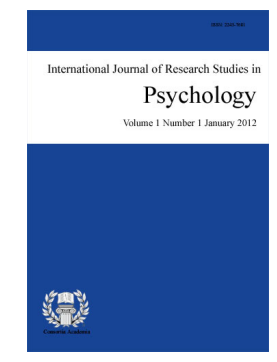

ISSN: 2243-7681 Online ISSN: 2243-769X

OPEN ACCESS

\title{
Abstract
}

This study focused on the reciprocal nature of leadership from the point of view of success, when defined a manifestation of expertise, high performances, productivity, and positive work experiences. Leaders' action with and among their employees formed the core of the study. The purpose was to find out how leaders themselves and their employees describe success at work and leadership practices that support the success. The study was conducted among leaders and employees in a mid-size Finnish enterprise. Two research questions were set for this study: (1) How do the leaders and supervisors describe successful leadership? and (2) How do the employees describe successful leadership? This study employed a multi method approach that combined qualitative research methods within one study. The leaders and supervisors $(\mathrm{N}=15)$ were interviewed while employees $(\mathrm{N}=29)$ participated by filling out an open-ended questionnaire. Elements of successful leadership in leaders' and supervisors' and employees' descriptions are presented as results. Leadership for success at work maintains that a leader or supervisor finds leadership as his or her personal strength. The social element of using the strength was strongly emphasized in this data. Much of the strength becomes manifested through the social interaction between leaders and supervisors and employees, where positivity can be the key element. Those who have this perception are likely to enjoy their work as leaders, find it meaningful, inspiring, and energizing, and to succeed as leaders and make followers succeed as well especially in the changing world of work.

Keywords: leadership; productivity; positive psychology; success at work; changing work 


\section{Success at work requires successful leaders? The elements of successful leadership according to leaders and employees of a Finnish mid-size enterprise}

\section{Introduction}

Success at work (see Uusiautti, 2008; Uusiautti \& Määttä, 2015) from a positive psychological viewpoint was under investigation in this study. The especial focus was on leadership practices that could enhance success at work among employees and leaders themselves. Previous studies in the field have outlined, for example, how to employ reward systems, motivation tools, and team work and people management skills as a part of leadership (Mumford, Zaccaro, Harding, Jacobs, \& Fleishman, 2000) as well as the psycho-social dimensions of work (e.g., Karasek and Theorel's Job Demand-Control model or Siegrist's Effort-Reward Imbalance model) that should be considered when aiming at increasing productivity. Likewise, the administrative scientific theories have defined the elements of good leaderships and traits of good leaders are abundant (see e.g., Maxwell, 1999; Spears, 2010).

From the positive psychological viewpoint to success at work, phenomena such as experienced meaningfulness are important in leadership (Uusiautti \& Määttä, 2014a; 2014b). Leaders can also create meaningfulness by acting as guides, motivators, and examples, as well as organizers of meaningful and enthusiastic doing at work (cf., Rutledge, 2009), which corresponds to the mission of the organization and the leader's vision (see Raynor, 1998). This is how everyone can achieve top performances and the sense of using their abilities to the fullest. Namely, such positive experiences enhance people's productivity, engagement (Hakanen, Perhoniemi, \& Toppinen-Tanner, 2008), problem-solving skills (Carver \& Scheier, 2005), and well-being (Judge, Locke, \& Durham, 1997).

When it comes to success, it is crucial that a leader has as clear understanding of the connection between these elements and practical work and supervision of work. This research was based on the idea that leaders and supervisors have a chance to act as guides, bellwethers, and examples as well as organizers of meaningful and inspiring work (see e.g., Rutledge, 2009). According to studies (e.g., Carver \& Scheier, 2005; Hakanen, Perhoniemi, \& Toppinen-Tanner, 2008; Niles, 2012), leaders who are able to sense and define the direction the organization should be led in are more likely to believe in their ideas of leadership and are more persistent to work to maintain motivated working and trust in positive development. Thus, they also have the chance to find means of supporting their employees' in the best possible ways which, for its part, promotes productivity and engagement as well as well-being and sense of meaning at work (see Achor, 2010). In sum, the leader's ability to perceive the meaning of each task and work in the organization in the big picture is crucial.

The experience of meaningfulness in a leader's personal working is greatly dependent on the compatibility of the leader's skills and abilities and the challenges at work (Uusiautti \& Määttä, 2014a; 2014b). Optimal work conditions that correspond to the leader's skills can lead to the greatest intrinsic work motivation (Deci \& Ryan, 2008; Ryan \& Deci, 2000) and proactivity (Covey, 2006) producing the experience of meaningfulness (Gardner, Csikszentmihalyi, \& Damon, 2001). Leaders' work includes decidedly great social and psychological demands (Kinnunen, Feldt, \& Mäkikangas, 2008) that necessitates that they are able to use various kinds of skills; leaders have to be able to align employees' knowledge, skills, and expertise with their conception of the desired development of the organization.

The most enjoyable experiences at work emerge from the sense of being in control of one's own action (Csikszentmihalyi, 2008). When it comes to leadership, it means that the leader can perceive the influence of his or her action in a large scale: how he or she as a leader can influence the outcomes and operations of the organization through his or her action? This sense of exercising power can be even addictive (e.g., San Juan, 2005). On the other hand, it can also be seen as an implication of having leadership as one's signature strength, when employing this strength provides the experiences of success and absorption, and the sense of being in the 
right work (Seligman, 2011).

Indeed, leadership as a human strength is a very multidimensional phenomenon but it is usually acknowledged as one of the human strengths especially in positive psychological research (see Seligman, 2002; 2011). Rath (2007) refers to leadership with a word "command", which is typical to people who have a compulsive need to share their vision and perspectives with others, take the reins, and who others find charismatic. Linley et al.'s (2010) strengths definition includes the concepts of enabler and strategic awareness to describe leadership. Leaders who are strong in the former can create conditions that allow people to develop and grow, while leaders with strong strategic awareness are able to perceive the big picture and factors influencing it widely and to make decisions that help them to reach their strategic goals (Linley et al., 2010).

Leadership is often connected with the idea of justice and ethical behavior (e.g., Sparrowe, 2008). Also when leadership is defined as a human strength, it has the connection to justice. According to Seligman et al. (2005), leadership is one of those strengths that manifest justice in a human being's action. In their definition, justice means citizenship skills that form the foundation of healthy society. Other human strengths connected with justice by Seligman et al. (2005) are fairness (equal and fair treatment of people) and teamwork (ability to act as a member of a group). Leadership in this viewpoint therefore means especially the ability to organize group activities and their realization. Leadership is a strength that, in many ways, relates to fair action with other people (e.g., van Knippenberg, De Cremer, \& van Knippenberg, 2007). For example, a study by Matthews et al. (2006) pointed out that leadership as a general strength is connected with several other features such as honesty and authenticity, hope, courage, diligence, and teamwork skills. Indeed, for example, authenticity in leadership is one of the current trends of leadership research (e.g., Gardner et al., 2011).

In all, the core of the psychology of human strengths is that some strengths are typical to some people, while others are not. Leadership is such a strength; it appears more powerfully in some people but not in all of us. In order to be one's signature strength, leadership action should feel fundamentally natural and pleasant, energizing-given that every work includes moments that are boring, difficult, or otherwise not pleasing. However, leadership can be seen a way to fulfill oneself within the limits or features typical of leadership (Csikszentmihalyi, 2008), that for example Rath and Conchie (2008) define as execution (the ability to make things happen), influence (the ability to sell ideas inside and outside the organization), relationship creation (the ability to notice factors that keep teams together), and strategic thinking (the ability to perceive the big picture and the desired outcome). Seligman (2002) has explained the experience of fulfillment as follows:

"If you can find a way to use your signature strengths at work often, and you also see your work
as contributing to the greater good, you have a calling. Your job is transformed from a
burdensome means into a gratification. The best understood aspect of happiness during the
workday is having flow-feeling completely at home within yourself when you work." (p. 173)

What is important in strengths is therefore to be able to use them. Linley et al. (2010) emphasize that strengths manifest a person's dominating ability to act, think, and feel in a way that enables their optimal action, development, and performance. In addition, strengths differ from behavior that can lead to a good performance but that does not produce the sense of self-fulfillment and is merely de-energizing. Realized strengths (Linley et al., 2010), signature strengths (Seligman, 2002), and theme strengths (Rath, 2007) are all concepts that refer to the somewhat same phenomenon: using one's strengths include a sense of control, energy, and high-level performance. According to Achor (2010), understanding this ideology in leadership is important not only for leaders' own performance but also for employees' improved performance-and well-being, as he calls it the happiness advantage.

This study focuses especially on the reciprocal nature of leadership. Leaders' action with and among their employees forms the core of the study. The purpose is to find out how leaders themselves and their employees describe success at work and leadership practices that support success. 


\section{Method}

\subsection{Research Questions and Approach}

The purpose is to describe success as the aim of leadership from the viewpoints of successful leadership when described by leaders and supervisors as well as employees of the target enterprise participating in this study. Two research questions were set for this study:

$>\quad$ How do leaders and supervisors describe successful leadership?

$>\quad$ How do employees describe successful leadership?

This part of the study leans on the earlier theoretical illustration of success at work (Uusiautti, 2008; 2013b; Uusiautti \& Määttä, 2015) and the psychology of human strengths (e.g., Seligman, 2011) as described in the Introduction. The aim is to find out how similar or different these groups' opinions on success and its prerequisites are, and how to enhance productivity and well-being in enterprises based on the findings of this study.

This study employed a multi method approach that combines qualitative research methods within one study (Ivankova, Creswell, \& Stick, 2006; Johnson \& Onwuegbuzie, 2004). This kind of approach was considered the best as the purpose was to obtain personal experiences and perceptions and analyze them qualitatively (Sale, Lohfeld, \& Brazil, 2002). The participants represent both leaders and supervisors, and employees of the target enterprise, and the combination of multi methods happens in the data collection phase: the leaders and supervisors were interviewed while employees participated by filling out an open-ended questionnaire. Before describing the study procedures in more detail, it is necessary to introduce the target enterprise to get a full picture of the study context.

\subsection{The Target Enterprise}

This study was conducted in mid-size banking enterprise located in northern Finland. The bank is a co-operative bank (quite similar to NCB in the USA), which is a part of a larger parent company in Finland. These independent subsidiaries are owned by their customers, and each bank operate in their own local market areas. The target enterprise of this study operates in the area of the province of Lapland with rough 180,000 inhabitants (1.98 pop per $\left.\mathrm{km}^{2}\right)$ in its 21 counties. It comprises 12 offices and is a very significant employer and provider of financing services in Lapland.

In addition to the chief executive officer, the enterprise has bank managers with their own areas of responsibility. Office managers supervise local offices across Lapland. Each unit at the main office in Rovaniemi is led by a supervisor. The units include, for example, enterprise services, real estate services, marketing, network and telephone services, administrative services, personnel administration, legal document production, legal services, debt collection, and accounting. The enterprise has about 130 employees in these banking services, financing, investments and legal advice. The services also include insurance products. Furthermore, the bank has a subsidiary, an estate agent company that has 12 agents as employees, who were also included in this study.

The values of the target enterprise, as stated in their mission statement, are "reliable northern-Finnish bank, ringside expert, and enabler of success". These ambitious goals are realized in the wide, sparsely-populated area of Finnish Lapland above the Arctic Circle.

\subsection{Data Collection}

The data collection took place in 2014. First, the leaders and supervisors were personally interviewed with the qualitative themed interview method. This method was chosen because in this study, the participants were 
The elements of successful leadership according to leaders and employees of a Finnish mid-size enterprise

seen as subjects whose perceptions and experiences should be obtained. Themed interviews allow participants express these in their own words, and interviews usually has the form of a conversation. In themed interviews, form and order of questions can vary but each theme is discussed in every interview (Creswell, 2009). In this study, the themes were mainly theory based: (1) the definition of success, (2) well-being and factors enhancing success at work, and (3) leadership practices that can enhance success and well-being and perception of oneself as a leader.

All leaders and supervisors were asked to participate in the study. Of 20 leaders and supervisors, 15 agreed ( 8 women and 7 men). They were personally interviewed at the main office of the bank or in offices located across Lapland. All interviews were recorded. The interviews provided useful information about the bank as a work place, basic function of each unit and office, and leadership principles and practices in the enterprise. I also received information about success factors and definitions as well as possible problems and challenges. This knowledge was used when designing employee questionnaires.

The questionnaire addressed all employees of the enterprise. The purpose was to find out their perceptions and experiences of the themes. The qualitative questionnaire method was chosen because the number of employees was relatively high. The questionnaire included 12 questions about themes of, for example, challenges and changes at work, work motivation, leadership practices, and work atmosphere. All employees $(\mathrm{N}=118)$ were emailed the request to participate in November 3, 2014. They could return the questionnaire by email or anonymously by regular mail. The deadline for replies was continued twice so that the final deadline was December 19, 2014. Only 29 employees (23 women, 6 men) participated. However, the questionnaire data appeared rich and useful. In addition, the participants represented relatively well the personnel of the company when compared the proportion of women and men, their age, and years of service. In December 2014, the whole personnel consisted of $82.4 \%$ women and $17.2 \%$ men, while in this study women formed $79.3 \%$ and men $20.7 \%$ of participants. In the whole personnel, the average age of women was 46.1 years and men 41.1 years while in these data; women were 45.9 years and men 37.4 years.

\subsection{Data Analysis}

The qualitative content analysis method was employed (Mayring, 2000). Content analysis can be data-based, theory-based, or theory-driven (Tuomi \& Sarajärvi, 2002). In this study, the data collection was led by theoretical framework, and therefore, also the data were initially analyzed with these theoretical concepts, that formed categories for the initial analysis. However, the items in categories were found with data-based analyses because the purpose was to find factors that emerge from data. Both sets of data were analyzed with the same principles. After this coding, the researcher can proceed to interpretations. The purpose of content analysis is to form a description of the target phenomenon in a general and concise form (Creswell, 2009). In this sub-study, the parts of data describing the elements of successful leadership were the target of analysis.

The analysis started by writing transcripts of the interview data and combining the questionnaire data into an electric form. Excerpts of the data are included in Results sections. To ensure anonymity, no identification codes are used for interviewees because it would be relatively easy to identify each participant in such a small group of leaders and supervisors. The data excerpts from the leader interviews are simply referred with "L/S". The employees in questionnaire data were given random codes. For example, the code "Q1" refers to the participant number 1 in the questionnaire data.

The interview data were analyzed by using various color codes to combine similar perceptions among leaders and supervisors. After the first round, I started to collect items in the categories under each theme: for example, it was possible to find various motivating factors such as goals, successes, and customer satisfaction. I also counted how many participants mentioned the items to secure that my interpretations would not be based on singular mentions. The questionnaire data were first analyzed question by question. Similarly, the researcher's notebook and color codes functioned as a help, and the thematic analysis was secured by counting the numbers 
of participants mentioning similar factors in the free form answers.

\subsection{Reliability}

Lincoln and Guba (1985) distinguish four criteria that help assessing qualitative research. They are credibility, transferability, dependability, and confirmability (see also Shenton, 2004). Credibility in this study was secured by selecting well-known research methods that were also previously familiar to the researcher. In addition, careful familiarization with the target company was necessary in the form of meetings with the CEO and the enterprise contact person nominated for the study. On the other hand, the phenomenon under study was extremely familiar to the researcher which made the designing and execution of the study fluent. A third way to improve credibility is related to participant selection. In this study, the goal was to recruit all leaders and supervisors, and employees, but, as any research involves, the participants are entitled to decline or draw from the study at any phase.

Transferability means the evaluation of how well the study can be transferred to another context. Qualitative research is always very context-bound which makes this criterion difficult to assess. However, careful descriptions of research methods, participant selection, data collection and analyses help the task. Likewise, the description of the study context is crucial, in this case, especially the understanding of the location of the enterprise as well as the special nature of the co-operative banking. Thirdly, dependability assess to what extent, the same methods used in the same conditions and with same participants can reach the same research results. The researcher's influence on data collection and interpretations can be critically viewed. Confirmability relates to objectivity. Like dependability also confirmability can be improved with rigorous description of study procedures and solutions as well as reflection on the researcher's position and preconceptions. Here, my background with research on success has directed the selection of theme and theoretical viewpoints, and analyses as well. On the other hand, this knowledge combined with earlier research experience with workers from various fields may have provided with insight on the phenomena taking place at workplaces. The strong interest in positive development and possibilities of positive action is the fundamental basis of the study.

\section{Results - Elements of Successful Leadership in Leaders' and Supervisors' and Employees' Descriptions}

\subsection{Coaching}

An organization's success requires always leadership. In the target enterprise, the idea of coaching was adopted as a part of leadership work recently. Some of the leaders did mention it as an important tool behind success. However, the leaders' opinions on the usability of coaching differed, mainly based on their own personalities and leadership styles. The differences between units and offices were mentioned too. The following data excerpt illustrates a leader who had found coaching as a suitable leadership approach:

\footnotetext{
"Somehow, I am so engaged nowadays - - to this coaching idea. In my opinion, fundamentally every employee whether they were at a supervisor level or at an employee level, those people are really motivated. Somehow this coaching, discussing things and bringing them out insightfully so that the person ponders to find out how he or she could develop in his or her work. - - At least my experience is that my followers are really enthusiastic and motivated to succeed and develop, and downright expect me to say something that they could develop." (L/S)
}

Coaching was connected with supporting employees' development in general. Work in bank had changed drastically during the past few decades toward sales, and therefore, the meaning of coaching was recognized in the interviews especially when teaching the employees about selling financing products to customers:

"The immediate supervisor's role in sales, in the coaching of selling, is incredibly important." $(\mathrm{L} / \mathrm{S})$ 
The elements of successful leadership according to leaders and employees of a Finnish mid-size enterprise

However, coaching does not always help all employees or a leader or supervisor can find coaching difficult. One of the interviewees described the outcomes of coaching with opposite examples:

\begin{abstract}
"If I hear that after coaching [the employee] has talked about what we agreed right away. - - So that [the employee] notices how good it feels after succeeding in something difficult new task. And that [the employee] understands that the results cannot improve if action does not improve. That is one point, but it is challenging. - - But certainly, I feel sometimes that I am toothless. That things do not go in the direction I was hoping. And sometimes I have been thinking that, after all coaching, should I just throw in the towel and quit coaching someone. - - If that own will does not appear in that employee." (L/S)
\end{abstract}

Coaching was reported to be based on open relationships between supervisors and employees. Progress should be made through positive dialogue. Some of the supervisors perceived coaching as a constant interaction with employees, while others used it as a way to seize on individual employees' needs for development at work:

\begin{abstract}
"But if there is something, I say immediately 'can we talk now'. I think we have such open, good relationship that they do not have to worry whether they could come to say something or whether this is too a minor matter." (L/S)

"I do sales and coaching meetings at least once a month. We look at the situation, how the month has gone, the sales month, how the employee has been thinking about the future, what has gone well and what could be developed." (L/S)
\end{abstract}

Employees emphasized the importance of supervisors' support and guidance as well. They were asked to analyze it especially from the perspective of their own success at work. The most important way of supporting employees' work was, according to the employees themselves $(\mathrm{N}=10)$, the supervisor's expertise and substance knowledge. They expected that the supervisor had wide knowledge and skills that they could help and guide employees when necessary. This was, therefore, closely related to the idea of coaching as well. The supervisors' expertise was described in many ways in the questionnaires:

"A top dude. Has done these grassroots work and thus understands us employees and knows what we do. Can guide, keeps us up-dated - - " (Q3)

"It is easy to go to talk with my supervisor and [the supervisor] helps also if I need support in my actual work because [the supervisor] is very competent." (Q27)

Other ways of providing support according to the employees $(\mathrm{N}=11)$ were positive feedback and spurring by the supervisor. Positive feedback was needed in the form of acknowledgement of successes and outlining new goals in coaching meetings. Support and spurring were considered especially important when the supervisor's expertise was evaluated lower than the employee's own.

\title{
3.2 Ensuring Productivity and Creating Optimal Working Conditions
}

The leaders and supervisors considered the ability to ensure good results and productivity as their most important task. Every interviewee pointed out this with slightly different emphases. Some leaders used results measurements as a leadership tool and emphasized their role as supporters and controllers of productivity. Some leaders were more inclined to think productivity through their abilities to enhance it. In the interviews, productivity meant especially employees' and teams' efficient working and reaching of goals. The following excerpts illustrate how the leaders and supervisors contemplated the issue:

"We measure results and go, that's it. - - Leadership is just a means to reach the goal, if you think it harshly.” (L/S) 
"I am responsible for this team and that, I am very goal-oriented. I like that we accomplish things that the employer demands from us.” (L/S)

One way to ensure good results was to place right people in right tasks. They emphasized how they as leaders should find out each employee's strengths and, whenever possible, distribute work so that they correspond employees' skills and abilities. The interviewees admitted that this requires plenty of activity and knowledge of human nature. On the other hand, the supervisors also had noticed that trust expressed toward employees was one way to increase productivity. Several supervisors stated that their employees were experts who would naturally do their best at work. Certainly, they had to intervene sometimes but

"the starting point is the trust in people doing their basic work. And if there are problems, we solve and discuss them together, and think what we are doing there." (L/S)

Seven of the employees participating in the research described the supervisors being the enablers and creators of optimal work conditions at their best. This brings out the employee viewpoint to the theme of productivity. Employees emphasized the supervisor's ability to notice changes in the atmosphere at work, listen to developmental suggestions, and support employees' abilities and skills:

“[The supervisor] has created such work conditions that I find it easy and fluent to do my job."

Ensuring productivity by creating good conditions did require devotion from supervisors, as stated by one of them in the interview:

"I am a little surprised that who much this support is sort of needed, by the boss, eventually. - -

That I have to use much of my work hours to support and related doing. But that is the leader's task." (L/S)

Leaders work as employees' supporters and bellwethers to promote productivity and to develop work methods. Many leaders also reported that they liked to lead through their example. Being a bellwether included the ability to bear responsibility over decisions made as a leader and to perceive the significance of one's work in a large scale:

"My strength is that I can quickly peace together things coming from different directions and make a synthesis and form a solid picture about what we are doing and what is happening." $(\mathrm{L} / \mathrm{S})$

"Surely I try to encourage people to realize that everything changes all the time and everyone should keep up with the wheel of development and not stick to the past. Now we do like this and learn these new [methods]. I try to encourage them to this and try to set an example that let us do like this and learn together if necessary." (L/S)

\subsection{Addressing Problems and Ability to Understand Employees' Work}

The interviewees described very clearly the hectic nature of banking business, including the huge changes in the daily work. From the perspective of leaders and their ability to ensure the success of the enterprise, they needed to make quick decisions and react fast. Ten of the interviewees described how important it is that leaders seize problems fast:

"If I notice that something is wrong or something has to be changes, I call the corps and we start brainstorming. I say that 'I think there is a problem, what we do now'.” (L/S)

Rabidity was described in many ways. Some leaders told that they reacted to the smallest deviations or cracks, while others supervised the situation and were focused on seeking solutions. Fast reactions were closely 
The elements of successful leadership according to leaders and employees of a Finnish mid-size enterprise

seen the way to ensure productivity as well, but they also emphasized that promptness was an important part of leadership in general.

"I look for those situations pretty much where something clicks. If I notice that this does not work. - - But I can recognize it quite well. Then, I also try to take care that they have a good atmosphere to work and good prerequisites to it. - - [describes a difficult situation] - - I just intervened and discussed. - - And then explained that why we do this." (L/S)

"I try to, if there are some flaws, immediately think how to change it to be smoother." (L/S)

Therefore, it was about the evaluation of work methods and basic conditions as well. Many supervisors reported that they had to evaluate them regularly, which required activity and problem-solving skills. Changes in individual employees' performances should also be actively checked and solved out if a problem occurred. The supervisor is responsible for finding out the problem but also hearing the employee's viewpoint was considered important:

"In that way I spur, and intervening in deviations is my main task when I lead these people. And I mainly look for reasons to know why we are not reaching goals and what we could do and whether I could help somehow. This is how it goes. - - Of course, we do mistakes and we screw up, but we have to learn from them." (L/S)

"Sometimes a supervisor is forced to do it, if someone does not perform well enough in the directors' opinion. Then we have these discussions. And we ask if every system is ok, computers work, expertise is up-dated, some work method hinders from succeeding. And together we try to think, as said, sometimes you have to say that this requires change, we cannot go on like this." $(\mathrm{L} / \mathrm{S})$

From the employees' perspective, successful problem solving necessitates that the leaders and supervisors understand employees' work. In addition to human management skills, the employees reported that the supervisor needs sufficient substance knowledge to make decisions in problematic situations. The support from an expert supervisor was perceived the most concrete and beneficial, while the opposite experience created mistrust of the supervisor:

“Especially good is [the supervisor's] expertise and ability to help in problems.” (Q22)

“The supervisor avoids personal contacts - - I think that [the supervisor] is insecure.”(Q23)

\subsection{Social Skills}

As implied in the previous data excerpt, leaders need the ability to work with people. To ensure productivity or solve problems at work is not likely to be successful, if the leader has not been able to create an open and appreciative atmosphere and interaction in the work unite. In this data, the leaders and supervisors mainly reported how they wanted to appear as dialogic and approachable leaders. On the other hand, they perceived that coaching could not be realized without an open dialogic culture.

"We talk with each other. Both get ideas to germinate in our minds. - - Usually, you find ideas in the colleague's thinking, and you have to return to it the next day to say that you were thinking about it. What you said, we should try it. It is quite brilliant, we should do it." (L/S)

Some leaders thought that open relationship with employees replaced coaching, at least when they had extra busy time at work and coaching meetings could not be arranged. Daily chatting moments and coffee breaks served as informal updates of work schedules and prospects of reaching goals. According to the leaders' and supervisors' experiences, this kind of relationships also enabled them to seize on problems quickly and helped to notice, for example, conflicts between employees: 
"I think I am a dialogic leader. - - You have to listen to your employees. - - When we have difficult issues, for example, difficult situations. Then we have to discuss and relieve the atmosphere and note that these are just things. And then, of course, how to say, encourage to move forward." (L/S)

Employees also analyzed the positive and negative practices in leadership action, which helped to spot those practices that they considered to enhance success at work the best. The employees appraised especially a positive attitude and openness in leaders and supervisors, and sort of humanity. The leaders' social skills and lack of them were described widely in the questionnaires. Some were happy of their supervisors' positive action and approachability, while others wished their supervisors would learn more about social interaction and social skills:

“Our team is led in a very humane manner and individuals are being noticed.” (Q22)

"There is always something to improve. And from my supervisor I would hope more presence, situational sensitivity, open constructive feedback, justice, encouragement, and support.” (Q9)

\subsection{Justice and Fairness}

Like was mentioned in the theoretical review, one core element connected with leadership is fairness. This was emphasized both in the leaders' and supervisors' interviews and in the employees' questionnaire answers. Seven leaders described how important it was to treat employees even-handedly. They had to consciously notice all employees and support fair play at the workplace in general:

"I do not know if that is the right word [refers to fairness] but that those rules are pretty much the same for everyone. That there is no slipping." (L/S)

"Clear limits, clear rules increase productivity and well-being. - - We really had to work with these basic thing awfully lot." (L/S)

The leaders and supervisors in this data talked about fairness very consciously when describing their ways of confronting employees and working with them. Many of them evaluated how they showed their fairness. Openness and honesty were described as important elements of fairness, in addition to avoiding favoring certain employees:

"At least, I try to be fair to people - - and that they would dare to come to say to me anything. And that I would consider anyone better than other. - - I would never ever indulge in something like that." (L/S)

Employees appreciated also fairness in leaders' action. Quite similarly to leaders, the employees emphasized avoiding of favoring and open sharing of information and communication. These features were described from positive and negative viewpoints. Those employees who perceived flaws in fairness surfaced situations in which they were not considered as individuals, treated unfairly compared to other employees, or not given accurate or timely information about the changes and new work methods in their unit.

"Changes and adjusting to them can cause some trouble. The supervisor's comments are not often positive. Although we have difficult times, we still could get/give some positive feedback. They anyway rank us based on our results" (Q7)

"Otherwise we are led quite well, but those work is not appreciated who are not doing sales and are not doing directly customer service” (Q27)

\subsection{Leader's Own Development and Efficiency}

The earlier result chapters have mainly described findings regarding the relationship between leaders and 
The elements of successful leadership according to leaders and employees of a Finnish mid-size enterprise

supervisors and employees. However, the interviews also brought out that a good leader does not only lead others and promote others' productivity, but also necessitates self-development and efficiency. When the leader's own development and efficiency were discussed the interviewees described feedback they received from their work as leaders, self-evaluations and up-dating their skills, and their self-knowledge.

Mostly, the leaders and supervisors considered feedback beneficial for their development. They got feedback from colleagues in the same positions, from their own supervisors, and sometimes from their employees. However, they admitted that it was difficult to it from them:

"I do hope that I would get feedback from my employees, but they rarely say anything like that, basically never. They do not think that I need feedback as well." (L/S)

"Some employees find it easier to give [feedback] and others never say anything. - Unfortunately, it is like that. Even if I prompted it, that if I do something crazy, give feedback to me directly. Whether it was good or bad." (L/S)

The leaders and supervisors considered feedback important when they wanted to develop their work with employees. In addition, the leaders thought what areas of leadership they would need to develop and which are different things to know to develop as a leader. Almost all interviewees, thirteen leaders and supervisors, talked about balancing between their so-called basic work and people leading. In other words, they found time management a crucial part of their success a leaders or development as leaders. Their own well-being was mentioned also in this context. The leaders recognized that successful leadership is not possible without a well-being leader who know his or her limits and is adjusted to his or her position as a leader. In practice, the leaders and supervisors were constantly looking for ways to work more efficiently. In order to develop their work and themselves as leaders, they had to study and learn new methods and attitudes, but quite often the solutions were found after trying them in practice. Likewise, distribution of work and various means to improve efficiency were considered.

"I guess I should use more time to it [coaching], but it is a fact that I cannot just coach someone. I have to do those things myself a lot too." (L/S)

"But I have been forced to practice it [delegating tasks], I mean practice really madly. I just had to, and you get used to it." (L/S)

"Then again, what I have been learning a lot, or practiced, and I always tell myself that I have to, despite the fact that I understand trouble or people, despite it, I have to demand results. And that is something I have been studying." (L/S)

Fundamentally, development as a leader is based on increasing self-knowledge. Leaders and supervisors are different, and they have their specific strengths and weaknesses-like everyone does. Recognizing them and admitting them are salient starting points to develop one's action as a leader. The most important thing is to find the most suitable means and methods to oneself as a leader, and listen to one's intrinsic feedback. This notion resembles much the idea of authentic leadership (e.g., Gardner, Cogliser, Davis, \& Dickens, 2011; Sparrowe, 2008).

"Surely, one feature of a leader should, in my opinion, be that you can identify or recognize that reflection, what you see in the mirror. And what you are capable of, what is not possible, and to recognize your own strengths, your own weaknesses, and to balance with them. - You can be a good leader in very many ways." (L/S)

Finally, honesty and authenticity means honesty toward employees as well. This kind of attitude creates a trustful and open atmosphere at the workplace: 
"[A leader] has to talk about things quite a lot. And sometimes you have to admit that a leader

can be wrong too. And that is very welcome too." (L/S)

\section{Summary}

The findings show how multidimensional the phenomenon of success and leadership is. Already the understanding of the concept of success could get roughly two different definitions (see also Uusiautti, 2015b): on the one hand, success was described as the results or outcomes and on the other hand, success could be seen as a process. When referring to the latter, success as a process, the elements of leadership became evident. This was to core of analysis in this study. The elements that best supported the success process covered leaders' action with employees but also leaders' own development.

The supervisors and leaders in this study described couching as a means of supporting employees' development (see also Grant \& Spence, 2013). Although not all leaders perceived the idea of couching similarly, they seemed to agree that in order to be able to support the employees' development, given especially the change in banking work, they had to create open and reciprocal relationship with their employees. Likewise, the data collected among employees of the target organization showed that they too appreciated the leaders' and supervisors' abilities to consult, support, and guide their work, in other words, lead their development.

In practical work, leaders emphasized also their responsibility for ensuring productivity and creating optimal working conditions as well as addressing problems and ability to understand employees' work. However, both leaders and employees seemed to appreciate social skills and fairness in leadership. All the features were discussed in the light of how they could enhance success at work, but similarly the participants addressed them from their negative experiences too. Leader's own development and efficiency was also described very practically. However, the leaders and supervisors referred to self-knowledge and awareness of their characteristics as leaders—-honesty and authenticity were seen important in this development as a leader person.

\section{Discussion}

According to various studies, by supporting employees' strengths and motivation, leaders and supervisors can create a work environment where employees are willing to help the organization to reach its goal (Winter \& Sarros, 2002). Likewise, Lo, Ramayah, and de Run (2010) noted that leaders' optimism and ability to enhance positive and enthusiastic atmosphere at work were the keys to survive in the demanding modern work life. These viewpoints are important for this study as well because the target enterprise had gone through a dramatic change, which meant that the contents of employees' work had altered totally requiring a downright change in personality in order to be successful at work. Successful leadership has to include, when interpreted from this perspective, optimism and positivity—hope (Niles, 2012; Snyder, 2002). Berson, Shamir, Avolio, and Popper (2001) noted that leaders' leadership abilities were connected to their optimism whereas passive leaders were not able to motivate or inspire their employees to work toward the vision or desired goals (see also Awamleh \& Gardner, 1999; Steger \& Dik, 2013). Many other studies have shown that excellent, charismatic leaders are inspiring and visionary (see Berson et al., 2001; Kirkpatrick, Wofford, \& Baum, 2002; Sosik \& Dinger, 2007); but how does this relate to success?

While employees' descriptions were limited to describe how leaders can help them and their units to succeed by creating opportunities to use strengths and optimal work conditions, in order to cope with changes, leaders had adopted the measurable goals as their leadership tool. However, the perceived best way to pursue the goals was to align the employees' skills with the goals of the enterprise (see also Stairs \& Galpin, 2013). The leaders reported that they had to work hard to recognize the employees' strengths, to support them, and to coach them—each with their personal style (see e.g., Boehm, Dwertmann, Bruch, \& Shamir, 2015). Work in the enterprise appeared, probably due to the recent changes, as work toward the goals without mentioning much the vision behind the operation. Employees did not mention it, while the leaders knew the meaning of the 
The elements of successful leadership according to leaders and employees of a Finnish mid-size enterprise

enterprise's vision to increase the well-being in the area the enterprise operates, but were not really able to describe how it influenced or was manifested in their daily work. Merely, the vision provided leaders a positive idea of the goals in general, and they pondered how to explain the vision to employees so that they could draw inspiration and motivation from it during the difficult and demanding phases of learning new skills and work methods. "Visioning relies on setting up for and encouraging ongoing synergy as part of organizational culture", state Kakabadse, Kakabadse, and Lee-Davies (2005, p. 245). Still, Sosik and Dinger (2007) remind that the vision does not have just an inspiring effect but a very practical role as well, in the form of concrete ideas to reach goals, which is extremely important in the changing world of work (Uusiautti, 2015a; 2015b; see also Pihie, Sadeghi, \& Elias, 2011; Polivy \& Herman, 2000; Thornberry, 1997).

Likewise, university leaders have reported their ability to create and shared a vision and lead employees toward that vision as an important positive feature of their work (Uusiautti, 2013a). This kind of action illustrates the multidimensional positive influence in organizations (see also Peterson \& Luthans, 2003). A vision partly produces the sense of meaningfulness in work unites but especially when leaders can use it alongside their leadership skills to help employees recognize and employ their strengths widely at work, and thus enhance their well-being at work while also the organization proceeds toward the desired goal (see also Strange \& Mumford, 2002; 2005). Therefore, the perceived meaningfulness includes the dimension of well-being as well (Liu, Siu, \& Shi, 2010), which provides a chance to understand the value of vision profoundly (Raynor, 1998). More studies on the concrete use and benefits of vision are needed, also from the employees' perspective.

Finally, one of the important purposes of the study was to analyze how leadership as a human strength might appear in this data in the light of leading for success. An active desire to recognize and familiarize with the employees' strengths, experiences, and opinions was, according to both leaders' and employees' descriptions of successful leadership, important (see also Berson \& Avolio, 2004). Employees respected leaders and supervisors who wanted to understand their work, provide guidance, give feedback, and spur them. Leaders and supervisors had, indeed, noted that especially during changes at work, successful leadership required open interaction and active motivating. Thus, leadership as a strength includes a strong aptitude to work with different kinds of people and to know them profoundly in order to find suitable tasks for them in the organization. Secondly, the leaders' own development was emphasized. To leaders themselves, it meant learning time management, learning people leading skills, taking care of their own well-being, and keeping their substance knowledge and skills updated. This requires leaders' self-knowledge and willingness to analyze their action and behavior as leaders. Leaders' development was important to employees too because they reported frustration with leaders' incapability to help in problem-solving due to lack of time or lack of substance knowledge. Fairness and honesty in leader-employee relationships were strongly emphasized on both data as well. Therefore, leadership as a strength includes also the dimension of willingness to develop and analyze oneself as a leader, a profound intrinsic motivation to act as a leader.

Leadership for success at work maintains that a leader or supervisor finds leadership as his or her personal strength (see also Peterson \& Park, 2006). The social element of using the strength was strongly emphasized in this data. Much of the strength becomes manifested through the social interaction between leaders and supervisors and employees. Positivity (e.g., Syväjärvi et al., 2014) is a key element to create an open and reciprocal atmosphere at work where everyone becomes heard and supported. It was worth noticing that also leaders longed for support or at least positive or constructive feedback from their followers. Fundamentally, a leader's work can be seen as a vocation; not differing too much from the attitude I recognized among nurses I studied a rough decade ago (Uusiautti, 2003). Leaders too need good self-knowledge and recognition of their strengths and weaknesses, and an idea of how their abilities become the best exploited at a leader's work (see also Mäkikangas, 2007). Those who have this perception are likely to enjoy their work as leaders, find it meaningful, inspiring, and energizing (see also Uusiautti \& Määttä, 2015), and to succeed as leaders and make followers succeed as well. 


\section{References}

Achor, S. (2010). The happiness advantage. The seven principles of positive psychology that fuel success and performance at work. New York, NY: Crown Business.

Awamleh, R., \& Gardner, W. L. (1999). Perceptions of leader charisma and effectiveness: The effects of vision content, delivery, and organizational performance. Leadership Quarterly, 10(3), 345-373. http://dx.doi.org/10.1016/S1048-9843(99)00022-3

Berson, Y., \& Avolio, B. J. (2004). Transformational leadership and the dissemination of organizational goals: A case study of a telecommunication firm. Leadership Quarterly, 15, 625-646. http://dx.doi.org/10.1016/j.leaqua.2004.07.003

Berson, Y., Shamir, B., Aviolio, B. J., \& Popper, M. (2001). The relationship between vision strength, leadership style and context. Leadership Quarterly, 12(1), 53-73. http://dx.doi.org/10.1016/S1048-9843(01)00064-9

Boehm, S. A., Dwertmann, D. J. G., Bruch, H., \& Shamir, B. (2015). The missing link? Investigating organizational identity strength and transformational leadership climate as mechanisms that connect CEO charisma with firm performance. Leadership Quarterly, 26, 156-171. http://dx.doi.org/10.1016/j.leaqua.2014.07.012

Carver, C. S., \& Scheier, M. F. (2005). Engagement, disengagement, coping, and catastrophe. In A. J. Elliot \& C. S. Dweck (Eds.), Handbook of competence and motivation (pp. 527-547). New York, NY: Guilford.

Covey, S. R. (2006). Tie menestykseen. 7 toimintatapaa henkilökohtaiseen kasvuun ja muutokseen [Road to success. 7 methods of personal growth and change]. (5th ed.) Jyväskylä: Gummerus.

Creswell, J. W. (2009). Research design. Qualitative, quantitative, and mixed methods approaches (3rd ed.) Thousand Oaks, CA: Sage.

Csikszentmihalyi, M. (2008). Flow. The psychology of optimal experience (10th ed.) New York, NY: Harper Perennial.

Deci, E. L., \& Ryan, R. M. (2008). Facilitating optimal motivation and psychological well-being across life's domains. Canadian Psychology, 49(1), 14-23. http://dx.doi.org/10.1037/0708-5591.49.1.14

Gardner, W. L., Cogliser, C. C., Davis, K. M., \& Dickens, M. P. (2011). Authentic leadership: A review of the literature and research agenda. Leadership Quarterly, 22, 1120-1145. http://dx.doi.org/10.1016/j.leaqua.2011.09.007

Gardner, H., Csikszentmihalyi, M., \& Damon, W. (2001). Good work. When excellence and ethics meet. New York, NY: Basic Books.

Grant, A. M., \& Spence, G. B. (2013). Using coaching and positive psychology to promote flourishing workforce: A model of goal-striving and mental health. In P. A. Linley, S. Harrington, \& N. Garcea (Eds.), The Oxford handbook of positive psychology and work (pp. 175-188). Oxford: Oxford University Press.

Hakanen, J., Rerhoniemi, R., \& Toppinen-Tanner, S. (2008). Positive gain spirals at work: From job resources to work engagement, personal initiative, and work-unit innovativeness. Journal of Vocational Behavior, 73, 78-91. http://dx.doi.org/10.1016/j.jvb.2008.01.003

Ivankova, N. V., Creswell, J. W., \& Stick, S. L. (2006). Using mixed methods sequential explanatory design: From theory to practice. Field Methods, 18(1), 3-20. http://dx.doi.org/10.1177/1525822X05282260

Johnson, R. B., \& Onwuegbuzie, A. J. (2004). Mixed methods research: A research paradigm whose time has come. Educational Researcher, 33(7), 14-26. http://dx.doi.org/10.3102/0013189X033007014

Judge, T. A., Locke, E. A., \& Durham, C. C. (1997). The dispositional causes of job satisfaction. Research in Organizational Behavior, 19, 151-188.

Kakabadse, N., Kakabadse, N., \& Lee-Davies, L. (2005). Visioning the pathway: A leadership process model. European Management Journal, 23(2), 237-246. http://dx.doi.org/10.1016/j.emj.2005.02.002

Karasek, R., \& Theorell, T. (1990). Healthy work. Stress, productivity, and reconstruction of working life. New York, NY: Basic Books.

Kinnunen, U., Feldt, T., \& Mäkikangas, A, (2008). Testing the effort-reward imbalance model among Finnish managers: the role of perceived organizational support. Journal of Health Psychology, 13, 114-127. 
The elements of successful leadership according to leaders and employees of a Finnish mid-size enterprise http://dx.doi.org/10.1037/1076-8998.13.2.114

Kirkpatrick, S. A., Wofford, J. C., \& Baum, J. R. (2002). Measuring motive imagery contained in the vision statements. Leadership Quarterly, 13(2), 139-150. http://dx.doi.org/10.1016/S1048-9843(02)00096-6

Lincoln, Y. S., \& Guba, E. G. (1985). Naturalistic inquiry. Thousand Oaks, CA: Sage.

Linley, A., Willars, J., \& Biswas-Diener, R. (2010b). The strengths book: Be confident, be successful, and enjoy better relationships by realizing the best of you. Coventry: CAPP Press.

Liu, J., Siu, O.-L., \& Shi, K. (2010), Transformational leadership and employee well-being: The mediating role of trust in the leader and self-efficacy. Applied Psychology: An International Review, 59(3), 454-479. http://dx.doi.org/10.1111/j.1464-0597.2009.00407.x

Lo, M. C., Ramayah, T., \& de Run, E. C. (2010). Does transformational leadership style foster commitment to change? The case of higher education in Malaysia. Procedia Social and Behavioral Sciences, 2, 5384-5388. http://dx.doi.org/10.1016/j.sbspro.2010.03.877

Matthews, M. D., Eid, J., Kelly, D., Bailey, J. K. S., \& Peterson, C. (2006). Character strengths and virtues of developing military leaders: An international comparison. Military Psychology, 18(Suppl), S57-S68. http://dx.doi.org/10.1207/s15327876mp1803s_5

Maxwell, J. (1999). The 21 indispensable qualities of a leader: Becoming the person others will want to follow. Nashville, TN: Yates \& Yates.

Mayring, P. (2000). Qualitative content analysis. Forum: Qualitative Social Research, 1(2). Retrieved from http://www.qualitativeresearch.net/fqs/fqs-e/2-00inhalt-e.htm

Mumford, M. D., Zaccaro, S. J., Harding, F. D., Jacobs, T. O., \& Fleishman, E. A. (2000). Leadership skills for a changing world: Solving complex social problems. Leadership Quarterly, 11(1), 11-35. http://dx.doi.org/10.1016/S1048-9843(99)00041-7

Mäkikangas, A. (2007). Personality, well-being and job resources. From negative paradigm towards positive psychology. Jyväskylä: University of Jyväskylä.

Niles, S. G. (2012). Career flow: A hope-centered model of career development. Journal of Employment Counseling, 48, 173-175. http://dx.doi.org/10.1002/j.2161-1920.2011.tb01107.x

Peterson, S. J., \& Luthans, F. (2003). The positive impact and development of hopeful leaders. Leadership \& Organization Development Journal, 24(1), 26-31. http://dx.doi.org/10.1108/01437730310457302

Peterson, C., \& Park, N. (2006). Character strengths in organizations. Journal of Organizational Behavior, 27, 1149-1154. http://dx.doi.org/10.1002/job.398

Pihie, Z. A. L., Sadeghi, A., \& Elias, H. (2011). Analysis of head of departments' leadership styles: Implication for improving research university management practices. Procedia - Social and Behavioral Sciences, 29, 1081-1090. http://dx.doi.org/10.1016/j.sbspro.2011.11.341

Polivy, J., \& Herman, C. P. (2000). The false-hope syndrome: Unfulfilled expectations of self-change. Current Directions in Psychological Science, 9, 128-131. http://dx.doi.org/10.1111/1467-8721.00076

Rath, T. (2007). StrengthsFinder 2.0. New York, NY: Gallup Press.

Rath, T., \& Conchie, B. (2008). Strengths-based leadership. Great leaders, teams, and why people follow. New York, NY: Gallup Press.

Raynor, M. E. (1998). That vision thing: Do we need it? Long Range Planning, 31(3), 368-376. http://dx.doi.org/10.1016/S0024-6301(98)80004-6

Rutledge, L. (2009). Teacher leadership and school improvement: A case study of teachers participating in the teacher leadership network with a regional education service center. Doctoral dissertation, Texas State University-San Marcos, USA.

Ryan, R. M., \& Deci, E. L. (2000b). When rewards compete with nature: the undermining of intrinsic motivation and self-regulation. In C. Sansone \& J. M. Harackiewicz (Eds.), Intrinsic and extrinsic motivation. The search for optimal motivation and performance (pp. 14-54). Thousand Oaks, CA: Academic Press. http://dx.doi.org/10.1016/B978-012619070-0/50024-6

Sale, J. E., Lohfeld, L. H., \& Brazil, K. (2002). Revisiting the quantitative-qualitative debate: Implications for mixed-methods research. Quality \& Quantity, 36, 43- 53. http://dx.doi.org/10.1023/A:1014301607592

San Juan, K. (2005). Re-imagining power in leadership: Reflection, integration, and servant leadership. 
International Journal of Servant-Leadership, 1(1), 187-212.

Seligman, M. E. P. (2002). Authentic happiness. New York, NY: FreePress.

Seligman, M. E. P. (2011). Flourish. A visionary new understanding of happiness and well-being. New York, NY: Free Press.

Seligman, M. E. P., Steen, T. A., Park, N., \& Peterson, C. (2005). Positive psychology progress. Empirical validation of interventions. American Psychologist, 60(5), 410-421. http://dx.doi.org/10.1037/0003-066X.60.5.410

Shenton, A. K. (2004). Strategies for ensuring trustworthiness in qualitative research projects. Education for Information, 22, 63-75.

Siegrist, J. (1996). Adverse health effects of high-effort/low-reward conditions. Journal of Occupational Health Psychology, 1, 27-41. http://dx.doi.org/10.1037/1076-8998.1.1.27

Snyder, R. (2002). Hope theory: Rainbows in the mind. Psychological Inquiry: An International Journal for the Advancement of Psychological Theory, 13(4), 249-275. http://dx.doi.org/10.1207/S15327965PLI1304_01

Sparrowe, R. T. (2005). Authentic leadership and the narrative self. Leadership Quarterly, 16, 419-439. http://dx.doi.org/10.1016/j.leaqua.2005.03.004

Sosik, J. J., \& Dinger, S. L. (2007). Relationships between leadership style and vision content: The moderating role of need for social approval, self-monitoring, and need for social power. Leadership Quarterly, 18, 134-153. http://dx.doi.org/10.1016/j.leaqua.2007.01.004

Spears, L. C. (2010). Character and servant leadership: Ten characteristics of effective, caring leaders. The Journal of Virtues \& Leadership, 1(1), 25-30.

Stairs, M., \& Galpin, M. (2013). Positive engagement: From employee engagement to workplace happiness. In P. A. Linley, S. Harrington, \& N. Garcea (Eds.), The Oxford handbook of positive psychology and work (pp. 155-172). Oxford: Oxford University Press.

Steger, M. F., \& Dik, B. J. (2013). Work as meaning: Individual and organizational benefits of engaging in meaningful work. In P. A. Linley, S. Harrington, \& N. Garcea (Eds.), The Oxford handbook of positive psychology and work (pp. 131-142). Oxford: Oxford University Press.

Strange, J. M., \& Mumford, M. D. (2002). The origins of vision. Charismatic versus ideological leadership. Leadership Quarterly, 13, 343-377. http://dx.doi.org/10.1016/S1048-9843(02)00125-X

Strange, J. M., \& Mumford, M. D. (2005). The origins of vision. Effects of reflection, models, and analysis. Leadership Quarterly, 16, 121-148. http://dx.doi.org/10.1016/j.leaqua.2004.07.006

Syväjärvi, A., Uusiautti, S., Perttula, J., Stenvall, J., \& Määttä, K. (2014). The reification of caring leadership in knowledge organizations. Research Journal in Organizational Psychology \& Educational Studies, 3(2), 93-105.

Thornberry, N. (1997). A view about “vision”. European Management Journal, 15(1), 28-34. http://dx.doi.org/10.1016/S0263-2373(96)00071-0

Tuomi, J., \& Sarajärvi, A. (2002). Laadullinen tutkimus ja sisällönanalyysi [Qualitative research and content analysis]. Jyväskylä: Gummerus.

Uusiautti, S. (2003). Neuvolatyöntekijöiden työssä kohtaamat muutokset - työn imuko selittäjänä? [Nurses' and midwives' experiences of changes at work - is work drive the key factor?]. Masteral thesis, University of Lapland, Rovaniemi, Finland.

Uusiautti, S. (2008). “Tänään teen elämäni parhaan työn” Työmenestys Vuoden Työntekijöiden kertomana ["Today, I'll work better than ever" Success at work described by the employees of the year]. Doctoral dissertation, University of Lapland, Rovaniemi, Finland.

Uusiautti, S. (2013a). An action-oriented perspective on caring leadership: a qualitative study of higher education administrators' positive leadership experiences. International Journal of Leadership in Education: Theory and Practice, 16(4), 482-496. http://dx.doi.org/10.1080/13603124.2013.770077

Uusiautti, S. (2013b). On the positive connection between success and happiness. International Journal of Research Studies in Psychology, 3(1), 1-11. http://dx.doi.org/10.5861/ijrsp.2013.509

Uusiautti, S. (2015a). Hope at work. In L. Bormans (Ed.), The world book of hope. Netherlands: Lannoo, in 

press.

Uusiautti, S. (2015b). Success at work requires the ability to life-long learning. Presented at the 4th International Conference on Education, 26-28 June 2015, St. Petersburg, Russia.

Uusiautti, S., \& Määttä, K. (2014a). Leaders' flow. In 2014 International Conference on Social Science and Management (pp. 51-56). Lancaster, PA: DEStech Publications.

Uusiautti, S., \& Määttä, K. (2014b). Perceived meaningfulness as the core of caring leadership. Venice 2014: International Conference for Academic Disciplines, June 30 - July 3, 2014, Universita' Ca' Foscari Di Venezia, Venice, Italy.

Uusiautti, S., \& Määttä, K. (2015). The psychology of becoming a successful worker: Research on the changing nature of achievement at work. London \& New York: Routledge.

van Knippenberg, D., De Cremer, D., \& van Knippenberg, B. (2007). Leadership and fairness: The state of the art. European Journal of Work and Organizational Psychology, 16(2), 113-140. http://dx.doi.org/10.1080/13594320701275833

Winter, R., \& Sarros, J. (2002). The academic work environment in Australian universities: A motivating place to work? Higher Education Research \& Development, 21(3), 241-258.

http://dx.doi.org/10.1080/0729436022000020751 
Uusiautti, S. 